\title{
İlköğretime Devam Eden Çocukların Ailelerinin Psikolojik Danışma Gereksinimlerinin İncelenmesi
}

DOI: $10.26466 /$ opus.634810

\author{
Ayşe Bengisoy* ${ }^{*}$ Melih Burak Özdemir ${ }^{* *}$ \\ "Yrd. Doç. Dr, Lefke Avrupa Üniversitesi, Dr. Fazıl Küçük Eğitim Fakültesi, Lefke/KKTC \\ E-Posta: abengisoy@eul.edu.tr \\ ORCID: 0000-0002-5269-5719 \\ ** Uzm., Lefke Avrupa Üniversitesi PDR Doktora Öğrencisi, Lefke/KKTC \\ E-Posta: mlhbrk52@hotmail.com \\ ORCID: $\underline{0000-0001-7016-0745}$
}

Öz

Çalışma 2018-2019 eğitim öğretim yılında KKTC'de ilköğretime devam eden 4. sınıf öğrencilerinin aile üyelerini kapsamaktadır. Yarı yapılandırılmış görüşme sorularına bağh olarak, 11 aile üyesinden çocuklarıyla yaşantılarda hangi konularda psikolojik gereksinime ihtiyaç duydukları, ne sıklıkla bunları yaşadıkları ve ne tür çözümler kullandıklarına dair sorunlar incelenmiştir. Yarı yapılandırılmış görüşme sorularl, araştırmacılarca literatür taraması ve kaynaklardan elde edilen bilgiler doğrultusunda hazırlanmıs ve sorular 5 alan uzmanı tarafından incelenerek, sorulara son şekli verilmiştir. 5 sorudan oluşan yarı yapılandırılmış görüşme formuyla görüşmeler 20-25' sürmüş ve görüşme bulguların hazırlamak için veriler kayıt altına alınmıştır. Aile üyelerinden 6'sı anne, 5'i babadır. Yaş ortalamalarıysa 35-44 yaşları arasındadır. Bulgular incelendiğinde, aile üyelerinin sık sık problemlerle karşılaştıkları; özellikle sınav kaygısı, zamanı iyi yönetememe, arkadaş-anne-baba ilişkilerinde sorun, sınıf-okul kurallarına uymama, tırnak yeme, vurma gibi problemlerle karşılaştıklarını, kendilerinin buldukları çözüm yollarının yetersiz kaldığını ve zaman zaman psikolojik danışman, psikolog veya psikiyatriye ihtiyaç duyduklarım ifade etmişlerdir. Tüm bunlara bağh olarak psikolojik danışma gereksinimi ve önemi çalışma bulgularında görülmektedir.

Anahtar Kelimeler: İlköğretim öğrencileri, psikolojik danışma gereksinimi, aile. 


\title{
Investigation of Psychological Counseling Needs of Families of Children in Primary School
}

\begin{abstract}
The study covers the family members of grade 4 students attending primary education in the 2018-2019 academic year. Based on the questions of 11 people and semi-structured interviews, the problems of the family members about the needs of psychological needs in the subjects with their children, how often they experienced them and what kind of solution alternatives they used were examined. Semi-structured interview questions were prepared in accordance with the literature review prepared by the researchers and the information obtained from the sources. The semi-structured interview consisting of 5 questions lasted for 20-25 minutes and the data was recorded to prepare the interview findings. When the findings obtained from the study are examined, 11 family members are 6 of them, 5 of them are father and their average age is between 35-44 years. Family members participating in the study often encountered problems, especially exam anxiety, time not to manage well, problems in the relationship between parents, problems in class, non-compliance with school rules, nail eating, hitting problems such as the problems they find themselves inadequate psychological counseling psychologist or psychiatry needs expressed Accordingly, the need and importance of psychological counseling can be seen in the study findings
\end{abstract}

Keywords: Primary school students, Psychological counseling needs, family 


\section{Giriş}

Sosyal sistemin en küçük birimi olan aile, insan yaşamını etkileyen en önemli unsurların başında gelmektedir. Çocuklar aile dediğimiz bu yapı içinde en iyi şekilde eğitim alır ve kişilik gelişimlerine bu yapı içinde şekil verirler (Herdem ve Bozgeyikli, 2013). Aile sistemi, çocuğun en temel psikolojik gereksinimlerinden olan sevgi ihtiyacın karşlayan bir sistemdir. Aile bu ihtiyacı karşılarken bir yandan da çocuğun bir gruba ait olma, güven içinde olma, saygı ve değer görme gibi sosyal ihtiyaçlarını da karşılar ve onu koruyan, destekleyen, eğiten ve öğreten işleviyle de sağlıklı bir ortam oluşturur. Aile fertleri bu yapı içinde hem aileye bağlı bir birey hem de bağımsız bir fert olarak kendini ifade etme ve gerçekleştirme firsatını elde eder (Özkan ve Kılıç, 2013). Fertlerin yaşamlarında önemli bir yer tutan aile, gerek konstrüktif (yapısal) özellikleri, gerekse de içinde taşıdığı ilişkiler sistemi gibi konular açısından farklı disiplinlerce incelenmiştir. Yapılan kuramsal çalışmalarla aile sistemi açıklanmaya çalışılmakta ve edinilen bilgiler özellikle uygulamalı alanlarda kullanılmaktadır. Psikolojik danışma ve rehberlik (PDR) de bu sözü edilen uygulamalı alanlardan biridir (Hamamcı ve Sevim, 2004).

Ebeveynler, çocuklarının öğretmenidirler ve bu noktada kimse bu rollerini onlardan alamaz. Okul dediğimiz yapı, anne babanın çocuğuna sağlayamadığı imkanları sunar ve çocuğun yeni ihtiyaçlarını karşılayıcı rolünü yerine getirir. Okul ve öğretmen bu noktada, ebeveynlerin eğitim etkinliğini tamamlar. Bunun için de okul-aile işbirliği şarttır. Okul-aile ilişkilerinin pozitif doğrultuda geliştirilmesi, iki tarafin da mutlu olması demektir. Okul ve aile dediğimiz yapılar kurdukları pozitif ilişkiyle aslında temelde çocukların gelişimlerini desteklemiş ve okulun amaçlarına hizmet etmiş olurlar. Okulla aile arasında kurulacak olan olumlu ilişkinin sıcak tutulması aslında iki tarafın da ortak ilgi alanı olan çocuğa yarar sağlayacağı aşikarıdır. Öğretmenler ve ebeveynler, birbirlerine bağlı rollerinin bilinci içinde oldukları takdirde sorunları aşabilirler (Cömert ve Güleç, 2004).

Okullar, sosyal açık sistemlerdir (Aydın, 2005, 161), yani hareketli özellikleriyle çevrelerini etkiledikleri gibi çevrelerinden de etkilenirler. Bu açıdan okulları toplumsal yapıdan, sosyal çevreden ayrı düşünmemiz imkansızdır. Okul dediğimiz sistemin sağlıklı işleyebilmesi büyük oranda uygun bir çevreyle mümkündür. Bu sistemin velilerle kuracağı sağlıklı iletişim de hiç 
kuşku yok ki sağlıklı bir çevrenin önkoşulunu oluşturacaktır (Yıldırım ve Dönmez, 2008).

Okul başarısını artıran etkenler üzerine yapılan çalışmalar, okul başarısında okulla aile arasındaki dayanışma varlığının önemli bir etken olduğunu ortaya koymaktadır. İlköğretim kademesine başlamasıyla birlikte, çocukların okul başarıları üzerinde rol oynayan çevresel etkiler, artık toplumun daha geniş bir kesimine doğru genişlemeye başlar. Ancak bu durum ailenin etkisinin bütünüyle ortadan kalktığı anlamına gelmez çünkü bir gün içinde çocuğun okulda geçirdiği zaman dikkate alındığında, zamanının daha büyük kısmını ailesiyle geçirdiği gerçeğini yadsıyamayız (Çelenk, 2003).

Düşünen ve işiten bir varlık olarak insan, günlük yaşam içerisinde gerek ailesel, gerek mesleki gerekse de bireysel pek çok sorunla karşılaşmakta ve bu problemlerle başa çıkarken de bazı tercihler yapmak, bazı kararlar almak ve yeni uyumlar yapmak zorundadır. Bilimsel ve profesyonel bir yardım olan rehberliğin merkezinde birey vardır. Bireyin kendini anlaması, çevresindeki imkanları tanıyarak doğru tercihlerle kendini gerçekleştirmesine yardım etmek amaciyla yapılan sistemli ve profesyonel yardım etme süreci olan rehberlik, bireye yardım etme sürecinin de özünü oluşturur. 'Yardım' ile ifade edilen aslında akıl vermek değil, farklı alternatifleri görerek en uygun olan seçeneği seçebilmesi için gerekli değerlendirmeyi yapabilecek düzeye gelmesine yardımcı olmaktır. Rehberlik hizmeti birey merkezli olup, süreklilik arz eden ve bireyin olduğu her yerde yapılabilen bir hizmetlerdir (Hatunoğlu ve Hatunoğlu, 2006).

Okul rehberlik servislerinin konsültasyon görevleri arasında sayabileceğimiz aile katılım programlarının yaygınlaştırılmasının ve okul-aile işbirliğinin güçlendirilmesinin, öğrencilerin her açıdan sağlıklı gelişimlerine katkı koyacağ1 ve farklı şartlara sahip pek çok ailenin desteklenmesi açısından önemli görülmektedir. Bireylerin akademik, bireysel ve sosyal gelişimlerine en üst düzeyde katkı koymak, eğitim sisteminin amaçları arasında yer almaktadır. Okulun ve ailenin işbirliği içinde olması, aile-okul tutarlılığını destekler ve bu tutarlılık da bireylerin gelişimlerine olumlu etki yapar. Ailenin, çocukların eğitimlerine aktif katılımı tüm dünyada önemsenmekte ve okul dediğimiz sisteminin de ayrılmaz bir parçası olarak görülmektedir (Özeke Kocabaş, 2006). 
Türkiye'de ilkokul, ortaokul ve lisede öğrenim gören öğrencilere dönük PDR hizmetleri kapsamında, ailelere yönelik olarak 'aile rehberliği ve danışmanlığı' hizmetleri yürütülür. Bu kapsam içindeki hizmetler doğrudan öğrenciye, dolaylı olarak da ailelerin vasitasıyla öğrencinin gelişim ve uyumunu hedef alan aile destek hizmetleridir. Bu hizmetler Rehberlik ve Araştırma Merkezi Müdürlükleriyle (RAM), ilkokul, ortaokul ve lise seviyesindeki okulların Pdr servislerince yürütülmektedir (ASAGM, 2008).

Kaya, Bölükbaşı, Macit ve Siyez, (2012) çalışmalarında, okullarda rehberlik servislerine yönelik olarak gerek velilerin gerekse de öğretmenlerin servise başvuru sebepleri arasında daha çok öğrenme güçlüğü, çocukların okula gitmek istememesi, ödevlerini yapmamaları, hırçın ya da saldırgan davranışlar sergilemeleri gibi problemlerin daha sıklıkla yer aldığı sonucuna ulaşmışlardır. 3. sınıfa kadar rehberlik servislerine başvuruların daha ziyade ebeveynler ve öğretmenler tarafından yapıldığı görülmektedir. Araştırmacılar bu bulguyu da, bu yaş grubu çocukların kendilerini tanıma, anlama ve ifade etmedeki sınırlılıklarıyla açıklamıştır. Bu bulgu, ilköğretim çağının ilk yıllarında ailelere ve öğretmenlere dönük yapılacak konsültasyon çalışmalarının da önemini ortaya koymaktadır. Aynı çalışmada ilköğretim ikinci kademede daha ağırlıkta olması kaydıyla, velilerin rehberlik servislerine başvuru sebepleri arasında akademik başarı da dikkati çeken bir başka konudur. Derslere çalışmama, okuldaki başarısızlık, motive olamama belli başlı akademik konular arasında yer almaktadır. Bu da eğitsel rehberliği işaret etmektedir. Rehberlik servislerine 1 . sinfftan sonra en fazla başvurunun ise 6 . ve 7 . sinıf düzeylerinde olduğu görülmektedir. Bu sınıf düzeylerinde yapılan başvurular daha ziyade öğrencilerce yapılırken; öğrencilerin rehberlik servislerine başvurma nedenleriyle, velilerin başvurma sebeplerinin ve öğretmenlerin öğrencileri rehberlik servislerine yönlendirme sebeplerinin farklı olduğu görülmüştür. Veli ve öğretmenler daha ziyade ebeveyn çatışması ve öğrenme güçlüğü gibi problemlerle rehberlik servislerine başvururken; 6. ve 7. sınıf öğrencileri ebeveyn çatışmasına ek olarak arkadaş ilişkileriyle ilgili konularda da rehberlik servislerine başvurmuştur.

Bu çalışma, rehberlik hizmetlerinin okullarda daha ziyade öğrencilere dönük bir hizmet olarak algılanması ve alan yazında konuyla ilgili yapılmış çalışmaların büyük kısmının öğrencilerin rehberlik ihtiyaçları üzerine yapılmış olması ve literatürde ailelerin psikolojik danışma ve rehberlik ihtiyaçları üzerine sınırlı çalışma olması ihtiyacından ortaya çıkmıştır. 


\section{Yöntem}

Bu çalışma KKTC Güzelyurt ilçesindeki Milli Eğitim ve Kültür Bakanlığı'na bağlı resmi bir İlköğretim okuluna devam eden 4. sinıf öğrencilerinin ailelerinin psikolojik danışma gereksinimleri ile ilgili görüşlerini ortaya koymayı amaçlayan betimsel bir çalışmadır. Araştırma 2018-2019 öğretim yılında gerçekleştirilmiştir.

Gözlem, görüşme ve doküman analizi nitel araştırmalarda yaygın olarak kullanılan tekniklerdir. Nitel araştırmalarda belli bir konu ya da olayın derinlemesine anlaşılması için veriler kapsamlı bir şekilde analiz edilip yorumlanır. Nitel araştırmalarda görüşme, gözlem ve yazılı kaynakların incelenmesi, üç çeşit veri toplama yöntemiyle yapılır. Görüşme yöntemi, kullanılan aracın özelliğine göre açı uçlu ve yapılandırılmış, görüşülen birey sayısına göre bireysel ya da odak grup, araştırmacının konumuna göre katılımcı ve katılımcı olmayan diye alt gruplara ayırmak mümkündür (Yıldırım ve Şimşek, 2011). Araştırılan konunun derinlemesine, ayrıntılı ve gerçekçi bir şekilde ele alınması nitel araştırmanın amaçlarındandır (Patton, 1990). 'Nitel araştırmalarda ulaşılan verileri analiz etmek için iki yöntem önerilir. Bu yöntemlerden biri betimsel, diğeri ise içerik analizidir. Betimsel analiz yöntemi verilerin yüzeysel işlenmesinde kullanılır. Derinlemesine analiz yapılmaz. Betimsel analiz yönteminde veriler daha önceden tasarlanan düşüncelere göre özetlenip yorumlanır' (Yıldırım ve Şimşek, 2005).

Bu çalışmada ilköğretim 4.sınıf devam eden çocuğu olan aile üyelerinin psikolojik danışma gerekliliği ile ilgili bakış açılarını, öğrencilerle hangi sıklıkla problem yaşadıklarını, kullandıkları çözüm yollarını, çözüm yollarının ne derece yeterli olduğunu, nerelerden yardım alınması gerektiğini, belirlemeye çalışılmıştır. Bunun yanında belirtilen birtakım problemlerden (ders çalışma, okul fobisi, uyum problemi, gece korkuları, öğrenme güçlügü̈, hiperaktivite) hangilerine yardımcı olabildiklerini, psikolojik danışmanların hangilerine yardımcı olabildiğini öğrenci velilerinden birebir dinlemek ve detaylı bir şekilde ortaya koyup açıklamak için yapılmıştır. Görüşme tekniği görüşme yapılan bireylerin bakış açılarını, kendi dünyalarını, duygularını ve düşüncelerini anlamak maksadıyla derinlemesine bilgi toplama firsatı tanır (Kuş, 2003). Görüşme tekniğinde veriler yüz yüze görüşme yardımıyla toplanır. Genellikle bireyler düşüncelerini açıklamak için sözlü anlatımı, yazılı anlatıma göre daha çok tercih ederler (Karasar, 2005). 
Kişilerin görüş ve tecrübelerinin, gözlemlerin ve doküman yoluyla elde edilen verilerin ayrıntılı bir şekilde ele alınması ulaşılan sonuçların geçerlilik ve güvenirlik göstergesi olarak değerlendirilir (Patton, 1990). Yapılan araştırmada, yarı yapılandırılmış görüşme tekniğinin kullanılma sebebi; bilgilerin derinlemesine alınmasına ve kişinin istediği bir şekilde cevap vermesine firsat tanınmasının sağlanmasıdır. Görüşülen kişilerden soruları içtenlikle cevaplamaları istenmiştir ve görüşme kayıtları veri olarak toplanmıştır.

\section{Araştırma Grubu}

2018-2019 eğitim öğretim yılında ilköğretime devam eden 4. sinıf öğrencilerinin aile üyelerini kapsamaktadır. 11 aile bireyiyle ( 6 anne 5 baba), yarı yapılandırılmış görüşme sorularına bağlı olarak, aile üyelerinden çocuklarıyla yaşantılarda ne tür konularda psikolojik gereksinime ihtiyaç duydukları, ne sıklıkla bunları yaşadıkları ve ne tür çözümler kullandıklarına dair sorunlar incelenmiştir. Velilerin yaş ortalamalarıysa ise 35-44 yaşları arasındadır.

\section{Veri Toplama Araçları}

Araştırmaya başlamadan önce ilköğretim sürecinde olan çocukların gelişimsel özellikleri ve ailelerinin yaşaması olası sorunları hakkında literatür taraması yapılmış; literatür taramasında yazılı kaynaklar, yayınlanmış makaleler, yüksek lisans ve doktora tezleri, ilköğretimde psikolojik danışmaya ihtiyaç duyulabilecek konular incelenerek derleme yapılmıştır. Bu veriler ışığında sorular oluşturulmuş, ve bu soruların incelenmesi ve değerlendirilmesi maksadıyla bu alanla ilgili uzman 5 akademik personele gönderilerek görüşleri alınmıştır. Genel olarak sorularda tutarlılığın olup olmadığını analiz etmek için ve kapsam geçerliliğine bakmak için uzman görüşlerine başvurulmuştur (Yurdagül, 2005). Uzman akademik personel soruların konu ile ilgili olup olmadığını ve anlaşılırlığını inceleyerek, geri dönüt vermiş ve bu doğrultuda 5 yarı yapılandırılmış açık uçlu soru oluşturulmuştur.

\section{Işslem}

Belirlenen aile üyeleri ile görüşmeye başlamadan önce 2 tane ilkokula devam eden çocuğa sahip aile üyesi ile deneme amaçlı görüşme yapılmış, sorular 
hakkında herhangi bir olumsuz geri bildirim alınmamış ve soru akışı tutarlı olduğu için sorular aynı şekilde kalmıştır. Katılımcılara görüşmenin amacını açıklayarak, nerede kullanılacağı hakkında bilgi verilmiştir. Ses kaydı yapmak için gerekli olan teklif yapılmış fakat 5 kişi olumlu, 6 kişi olumsuz baktığından, bu 6 kişi ile de görüşmelerde yazılı kayıtlar yapılmıştır. Görüşmelerin tamamı yüz yüze yapılmıştır. Görüşmeler yaklaşık $20-25$ dakika sürmüştür. Görüşme bulgularını hazırlamak için veriler kayıt altına alınmıştır. Bu araştırmanın verileri nitel araştırma yöntemi olan yüz yüze görüşme yöntemi ile toplanmıştır. Görüşme vasıtasıyla ulaşlan veriler, görüşmeye katılan kişilerin tecrübelerini, görüşlerini, duygularını ve bilgilerin doğrudan aktarımını kapsar (Patton, 1990).

\section{Verilerin Analizi}

Araştırmada, yüz yüze görüşme yoluyla elde edilen veriler, yazılı doküman haline getirilmiş ve betimsel analiz tekniği ile analiz edilmiştir. 'Betimsel analiz, verilerin yüzeysel analizinde kullanılır, detaylı analiz gerektirmez. Bu şekilde elde edilen veriler önceden belirlenen temalar doğrultusunda özetlenerek yorumu yapilır'(Ekiz, 2013).

Betimsel analiz, içerik analizi ile kıyaslandığı zaman daha yüzeysel bir yöntemdir ve veriler değiştirilmeden aktarılır. Betimsel analizde aynı soru hakkında farklı düşünen kişilerin düşünceleri yer alır. Verileri sınıflandırarak ve özetlenerek sonuçlara ulaşılır. Görüşmelerden elde edilen veriler, önceden belirlenen başlıklar altında toplanarak yorumlanır. Veriler araştırma sorularına göre ya da verilerin toplanma aşamasında elde edilen ön bilgiler doğrultusunda da düzenlenebilir (Ekiz, 2013).

Betimsel analiz dört aşamadan oluşur (Yıldırım, 2006):

1. Çerçeve oluşturma

2. Çerçeveye göre bilgilerin işlenmesi

3. Bulguları tanimlama

4. Bulguları yorumlama

Görüşmeye katılan her bir aile üyesi için sıra ile farklı bir kod kullanılmıştır. Her bir aile üyesine $\mathrm{K} 1, \mathrm{~K} 2, \mathrm{~K} 3, \mathrm{~K} 4, \mathrm{~K} 5, \mathrm{~K} 6, \mathrm{E} 7, \mathrm{E} 8, \mathrm{E} 9, \mathrm{E} 10, \mathrm{E} 11$ şeklinde kod numaraları verilmiştir. Görüşmede toplanan verilerde herhangi bir değişiklik 
yapılmadan yazılı doküman haline getirilmiştir. Yazılı materyal haline getirilen görüşmeler, her bir soru maddesinin altında kategoriler oluşturulmuştur. Alıntılara hiç değiştirilmeden yer verilmesi ve bunlara dayanarak sonuçların açıklanması, değerlendirilmesi, araştırmanın geçerliliğinin ve güvenirliliğinin sağlanması açısından oldukça önemlidir (Yıldırım ve diğ., 2006). Bu yüzden bu araştırmada doğrudan alıntılara yer verilmiş ve veriler ışığında sonuçlar açıklanmaya çalışılmıştır.

\section{Bulgular}

Tablo 1. Görüşmeye katılan ailelerin özellikleri

\begin{tabular}{lllll}
\hline Kod & Cinsiyet & Yaş & Öğrenim Durumu & Meslek \\
\hline 1 & $\mathrm{~K}$ & 35 & Lisans & Öğretmen \\
2 & $\mathrm{~K}$ & 40 & Lisans & Memur \\
3 & $\mathrm{~K}$ & 38 & Lisans & Banka Memuru \\
4 & $\mathrm{~K}$ & 41 & Lisans & Öğretmen \\
5 & $\mathrm{~K}$ & 42 & Lise & Ev hanımı \\
6 & $\mathrm{~K}$ & 37 & Lise & Ev hanım \\
7 & $\mathrm{E}$ & 44 & Lisans & Memur \\
8 & $\mathrm{E}$ & 38 & Lisans & Memur \\
9 & $\mathrm{E}$ & 41 & Lisans & Memur \\
10 & $\mathrm{E}$ & 39 & Yüksel lisans & Avukat \\
11 & $\mathrm{E}$ & 42 & Lisans & Polis \\
\hline
\end{tabular}

Araştırmaya 11 aile üyesi katılmıştır. Bu ailelerin 6'sı kadın 5'i ise erkektir. Kadınların 35-42 yaş arasında olduğu erkeklerin ise 38-44 yaşları arasında olduğu görülmektedir. Kadınların 4'ünün lisans 2'sinin ise lise mezunu olduğu, erkeklerin ise 4'ünün lisans 1 tanesinin ise yüksek lisans mezunu olduğu görülmektedir. Ayrıca meslekleri incelendiğinde, 2 kişinin öğretmen, 2 kişinin ev hanımı, 4 kişinin memur, 1 kişinin banka memuru, 1 kişinin polis ve 1 kişinin de avukat olduğu görülmektedir.

Tablo 2. Çocuklarda yaşanan psikolojik problemlerin sıklı̆̆ı ile ilgili görüşler bulgular Öğrencilerde yaşanan psikolojik problemlerin sıklığı ile ilgili görüşler $\mathrm{f}$ Sık sık karşılaşıyorum

Tablo 2'de görüldüğü gibi kendileriyle görüşülen aile üyelerinden 9'u çocuklarının sık sık psikolojik problemler yaşadığı, ikisi çocuklarının bazen psikolojik problemler yaşadığını belirtmişlerdir. 
Tablo 3. Öğrencilerde karşılaşılan psikolojik problemlerle ilgili görüşler

Öğrencilerde karşılaşılan psikolojik problemler ile ilgili görüşler-bulgular

Sinav kaygisı

Arkadaş ilişkilerinde problem

Anne baba ile ilgili problemler

Şiddete yönelme

Zamanı kontrol edememe

Tirnak yeme

Vurma davranışı

Tablo 3'de görüldüğü üzere öğrencilerde karşılaşılan psikolojik problemler sıralandığında en çok sınav kaygısı ki bunu 11 veli ifade etmiş, 10 kişi çocuğun arkadaş ilişkilerinde problem yaşadığı, 9 kişi çocukta anne baba ile problemlerinin olduğu, 8'i çocuğun şiddet içerikli davranışlarının olduğunu, 7 'si zamanı kontrol edemediklerini, 6'sında tırnak yeme davranışının bulunduğunu, 5'i çocuklarının çalışma konusunda isteksizlik yaşadığı ve gelecek hedeflerinin olmadığını, 4'ü çocuklarının arkadaş ve öğretmenlerine karşı saygısızca tutumlar sergilediğini, 3 ’ü çocuğun okul fobisi yaşadığını ve öğrenme güçlüğü/hiperaktivitesinin olduğunu, 2'si ise çocuklarının sınıf ve okul kurallarına uymakta zorlandıklarını ifade etmişlerdir.

Tablo 4. Ailelerin çocuklarında karşılaştıkları psikolojik problemler karşısında başvurdukları çözüm yolları ilgili görüşler

\begin{tabular}{lc}
\hline $\begin{array}{l}\text { Ailelerin çocuklarında karşılaştıkları psikolojik problemler karşısında başvurdukları } \\
\text { çözüm yolları ilgili görüşler }\end{array}$ & $\mathrm{f}$ \\
\hline Çocukla konuşurum & 11 \\
\hline Öğretmeni ile görüşürüm & 10 \\
\hline Sevdiği şeylerden mahrum bırakırım & 6 \\
\hline Uzmana gönderirim & 5 \\
Okuldaki özel eğitim uzmanından yardım isterim & 2 \\
\hline Özel ders öğretmeninden destek isterim & 1 \\
\hline Diğer ailelerden fikir alırım & \\
\hline
\end{tabular}

Tablo 4. te görüldüğü gibi çocuklarda görülen psikolojik problemler karşısında 11 aile üyesi, çocuklarıyla konuştuklarını, 10'u öğretmen ile gö- 
rüşmeyi tercih ettiğini, 5'i uzmana (rehber öğretmen, psikolog vb.) gönderirim, 6'sı sevdiği bir şeyden mahrum bıraktığını, 3'ü okuldaki özel eğitim uzmanından yardım talep edeceğini, 2'si özel ders öğretmeninden yardım isteyebileceğini ve 1 kişi de diğer ailelerden fikir aldığını ifade etmişlerdir.

Tablo 5. Aile üyelerinin başvurduğu çözüm yollarnnın yeterlilik derecesi ile ilişkin görüşler

\begin{tabular}{lc}
\hline Aile üyelerinin başvurduğu çözüm yollarının yeterlilik derecesi ile ilişkin görüşler & $\mathbf{f}$ \\
\hline Yeterli değil & 9 \\
Orta derecede yeterli & 1 \\
Yeterli & 1 \\
\hline
\end{tabular}

Tablo 5. de görüldügü gibi, 9 kişi öğrencilerin problemlerini çözmek için başvurdukları çözüm yollarının yeterli olmadığını, 1 kişi başvurduğu çözüm yollarının orta derecede yeterli olduğunu, 1 kişi ise çözüm yollarının yeterli olduğunu belirtmişlerdir.

- E 10: ‘Çocuğumla ilgili sorunlarmmizı çözüyoruz ancak sonra tekrar tekrar ortaya çıkıyor bu da problemin bitmediğini gösteriyor. Bu durumda desteğe ihtiyaç duyuyoruz.

- K3: ‘Çocuğumla geçirdiğim zaman kısıtlı. Sorunlarım çözmek için hem öğretmenlerinin yardımına hem de benim destek vermem gerekliliğine inanıyorum. O yüzden yeterli değil bu durum'.

Tablo 6. Aile Üyelerinin yaşanan psikolojik problemler karşısında nerelerden yardım alınması gerektiği ile ilgili görüş̧ler

\begin{tabular}{ll}
\hline $\begin{array}{l}\text { Aile Üyelerinin yaşanan psikolojik problemler karşısında nerelerden yardım alınması } \\
\text { gerektiği ile ilgili görüler }\end{array}$ & $\mathrm{f}$ \\
\hline $\begin{array}{l}\text { Psikolojik Danışman ve Rehber/ psikolog/psikiyatrist } \\
\text { Öğretmen }\end{array}$ & 10 \\
\hline
\end{tabular}

Tablo 6. da görüldüğü gibi on tane aile üyesi yaşanan psikolojik problemler karşısında psikolojik danışman ve rehber, psikolog ve psikiyatrist gibi uzmanlardan yardım alınması gerektiğini düşünüyor. Bir kişi ise öğretmenden yardım alınması gerekliliğini ifade etmektedir.

E11 ‘Bazı problemler öğretmenle de çözülebilir. Mesela sınav kaygısı ve zaman yönetiminde bize öğretmen yardım etmeli. Bu çocuklar sınavlarda kaygı yaşar ve zamanını iyi kullanamazlar bence bu süreç okul ortamında çalışlabilir'. 


\section{Tartışma}

Bu çalışmayla, ilkokul 4. sınıfa devam eden öğrenci velilerinin, psikolojik danışma gereksinimleriyle ilgili görüşlerinin ortaya konması amaçlanmıştır. Araştırma bulgularına baktığımızda temel olarak ailelerin çocuklarıyla ilgili olarak; sınav kaygısı, arkadaş ilişkilerinde ve anne babayla yaşadıkları problemler, çocuklarının şiddet içeren davranışlar sergilemeleri, tırnak yeme, öğrenme güçlüğü, hiperaktivite, çalışma isteksizliği, okul fobisi, gelecek hedeflerinin olmayışı, sınıf/okul kurallarına uymada sorun ve çocuklarının zaman yönetimi noktasında sorunlar yaşadıklarını belirtmişlerdir.

Literatür tarandığında, araştırma bulgularımızdan elde ettiğimiz sonuçları destekler nitelikte çalışmalar alan yazında mevcuttur. Bulgulara göz attığımızda ailelerin en çok ifade ettikleri sorun alanı 'sınav kaygısı' dır. Alan yazında bu bulguyu destekler çalışmalar mevcuttur ve literatür tarandığında sınav kaygısıyla ilgili pek çok araştırmanın olduğu ve konunun güncelliğini koruduğu gözlenmektedir. Şahin, Günay, Batı (2006), Yıldırım (2007) çalışmalarında, öğrencilerde yüksek sınav kaygısı sonuçlarına ulaşmışlardır. Putwain ve Best (2011) ilkokul öğrencileri üzerinde yaptıkları çalışmalarında, öğretmenlerin sınavın tehdit olarak algılanmasına sebep olabilecek açılamalar yapmalarını, öğrencilerin daha fazla sınav kaygısı yaşamalarına sebep olabileceği sonucuna ulaşmışlardır (Demirci ve Erden, 2016). Casbarro (2005) çalışmasında ise öğretmenlerin sınıf ortamında sınavla ilgili verdiği bilgilerin ve bu bilgileri paylaşma şekillerinin, sınav kaygısını ortaya çıkarabildiği sonucuna ulaşmıştır (Demirci ve Erden, 2016). Sınav kaygısı sebebiyle yardım alan öğrencilerde, başta dikkat eksikliği ve hiperaktivite bozukluğu (DEHB) olmak üzere, depresyon ve sosyal anksiyete gibi bozuklukların varlığı aranmalıdır (Kavakçı, Güler ve Çetinkaya, 2011). İnsan yaşamının her evresinde önemli bir yer tutan sınav kaygısının ne olduğu, hangi değişkenlerle ilişki içinde olduğu, sınav kaygısıyla başa çıabilmek için nelerin yapılması gerektiği güncelliğini koruyan bir konudur. Bu noktada, sınav kaygısını önlemeye dönük ve sınav kaygısını kontrol etmeye yardımcı olacak çalışmalar, öğrenci başarısını arttıracak, derslere, öğretmenlere, okula ve hayata daha pozitif bakmalarının yolunu açabilecektir (Demirci ve Erden, 2016). Bu çalışma sonuçları da bulgularımızı destekler niteliktedir.

Çalışmamızda, aileler tarafından öğrencilerin sorun yaşadıkları problem alanları içerisinde arkadaşları ile yaşadıkları problemler ve öğrenme güçlüğü 
ifade edilmiştir. Alan yazında yapılmış olan çalışmalar bulgularımız destekler niteliktedir. Nalbant ve Bababoğlu (2016) çalışmalarında, öğrencilerin okulda arkadaş, öğretmen ve yöneticilerle problem yaşadıkları sonucuna ulaşmışlardır. Uğur Baysal, Özmen, Parman, Sahip, Bulut ve Gökçay (2004) çalışmalarında, öğrenme güçlüğü ve davranışsal problemlerin çoğunlukla yaşanılan problemler olduğu sonucuna ulaşmışlardır. Diğer ülkelerde yapılan araştırmalarda da bu sonuca yakın sonuçlar elde edilmiştir. Bu çalışmaların sonuçlarının, araştırma bulgularımızla örtüştüğü söylenebilir.

Şiddet de ifade edilen bir başka sorun alanıdır ve literatür ile örtüşmektedir. Koruyucu tavır sergileyen anne babalar çocuklarıyla aşırı ilgilenmekte ve onlar adına her şeyi kendileri yapmak istemektedirler. Çocuklarını gereğinden fazla denetleyerek onların bağımsız bireyler olarak yaşamalarına olanak tanımamaktadırlar. Bu tutum, çocuğu bağımlı, kendine karşı güvensiz, karar alamayan, silik bir kişi yapmakta, aile içinde ve dışında sosyal uyum problemleri yaşayan bir birey haline getirebilmektedir (Özgüven, 2001: 213, 215) İlgisiz ebeveyn tutumu ise; kızgın, saldırgan, kavgacı, içe dönük, bastırılmış bir kişiliği ortaya çıkabilmektedir (Özgüven, 2001: 215- 216). Ebeveynlerin çocuklarına karşı ilgisiz ve kayıtsız tavrı, çocuğun öğretmen, arkadaş ve yakın çevresindeki eşyalara verdiği zarar ve suçluluk duygusu arasında ilişki bulunmuştur. Araştırma bulguları, ilgisiz ve kayıtsız anne baba yaklaşımının, çocuktaki saldırganlık eğilimini güçlendirdiğini ortaya koymaktadır (Yavuzer, 2003: 33). Bu çalışma sonuçları da şunu ortaya koymaktadır ki aile içerisinde ebeveyn tutumları, çocukların gerek aile içerisinde gerekse de aile d1şında sergiledikleri davranış problemleri üzerinde oldukça etkilidir. Salı (2014) çalışmasında akranları tarafından şiddete maruz kalan çocukların, akranlarına dönük saldırganca, asosyal ve korkulu/kaygılı davrandıkları, akranlarınca dışlandıkları, aşırı hareketli oldukları, akranlarına dönük yardım amaçlı sosyal davranışları da daha az gösterdikleri sonucuna ulaşmıştır. Gudlaugsdottir,Vilhjalmsson, Kristjansdottir, Jacobsen ve Meyrowitsch (2004) yaptıkları çalışmalarında, erkek cinsinin, ebeveynlerinden yeterli destek alamamasının, okuldaki başarısızlıklar ve ailedeki kötü olaylar gibi olumsuz yaşantılar; sinir, agresiflik, ve güç kullanımının tümünün orta yetişkinlik döneminde şiddet davranışlarının ortaya çıkışıla ilişkili olduğunu saptamıştır. Panayiotis, Anna, Charalambos ve Chrysostomos (2010) çalışmalarında 
Kıbrıs'taki ilkokul ve lise öğrencileri arasındaki şiddet eğilimlerinin yaygınl1ğını araştırmış ve toplamda, Kıbrıslı Rum ögrencilerin \%17'sinin şiddet uygulayan taraf olma ve kurban olmanın birkaç değişik biçiminde dahil olduğu saptanmıştır. Gentile, Lynch, Linder ve Walsh (2004)'teki çalışmalarında kendilerini aşırı derecede video oyunu şiddetine maruz bırakan gençlerin daha düşmanca tavırlar sergilediği, öğretmenleriyle daha sık tartışmalar yaşadığ1 sonucuna ulaşırken; fiziksel kavgalarda bulunma ihtimallerinin de daha yüksek olduğu ve okulda daha başarısız oldukları tespit etmişlerdir. Bu bulgular çalışmamızı destekler niteliktedir.

Sezer, Kolaç ve Erol (2013) çalışmalarında, ilköğretim çağındaki öğrencilerin saldırganlık düzeylerini düşük bulmuş ancak saldırganlığın, ebeveynlerin kavga etme sıklığı ve ebeveyn tutumu değişkenlerden etkilendiği saptamıştır. Saldırganlığın sonradan kazanıldığıyla ilgili en önemli çalışma sosyal öğrenme kuramıdır. Bu kuram, saldırganlık ve şiddetin, nesiller boyunca öğrenilmiş bir davranış kalıbı olarak geçtiğini savunmakta ve çocukların model aldıkları ebeveynlerinin davranışlarından nasıl davranmaları gerektiğini öğrendiklerini, gerek ailelerinden gerekse de sosyal çevreden edindikleri saldırgan modellere özenerek saldırgan davranışlar sergilediklerini ileri sürmektedir (Eroğlu, 2009). Aile içerisinde anne babalar sorunlarını kavga ederek çözmeye çalışıyorsa, çocuklar da aynı şekilde sorunlarını kavga ederek çözme yoluna gidecektir (Taner, 2011). Sezer, Kolaç ve Erol (2013) çalışmalarında, anne babası bazen ya da her zaman kavga eden öğrencilerin saldırganlık puan ortalamalarını, hiç kavga etmeyenlere göre daha yüksek bulmuştur. Alan yazında yapılan çalışmalar, son yıllarda şiddet içerikli filmlerdeki kahramanları kendilerine rol model alan çocukların, bu kahramanları zamanla kimlikleriyle de özdeşleştirmektedir. Film kahramanları kötülere karşı şiddet kullanarak galip gelmekte, çocuklar da bu açıdan şiddeti çözüm yolu, iletişim aracı olarak görmeye başlamaktadır (Işık Taner, 2011). Gürsu (2015) gerek çocukların ve gerekse de ergenlerin zamanlarının büyük kısmını internet başında geçirdiği bir gerçektir. Bu da çocuklarda, zaman içinde akranlarına k1yasla şiddet eğilimi, yalnızlaşma, akademik başarısızlık, vicdan duygusunun körelmesi, hiperaktivite, dikkat dağınıklığı, depresyon, içedönüklük, yalıtılmışlık, tek tipleşme, sosyal ilişki kaybı, obezite gibi psikolojik ve fizyolojik sorunlar oluşturmaktadır. Tüm bu sonuçların araştırma bulgularımızla örtüştüğü söylenebilir. 
Davranış problemi sergileyen çocuklar, arkadaşlarınca dışlanabildikleri gibi onlardan öğrenebilecekleri bazı sosyal becerilerden de yoksun kalabilmektedir (Erbaş, 2002). Davranış problemleri zamanla ya da çocuk büyüdükçe bırakılabilmektedir. Örneğin, tırnak yeme davranışı 4-8 yaşları arasında ortaya çıkmakta ve genellikle ergenlik döneminin sonlarına doğru terk edilmektedir. Tırnak yeme davranışıla çocuk gerilimi, sıkıntıyı yok eden bir sakinleme ve başarı duygusu yaşarken, diğer taraftan çocuğun suçluluk duygusuyla kendini cezalandırma isteğinden kaynaklı içe yöneltilmiş saldırganlık ya da sosyal çevreyle tersleşerek ilgi çekme ya da güvensizlik duygusunu da içerebilmektedir (Minibaş, 1988). Yörükoğlu (1982) araştırma sonuçlarına göre, tüm değişkenlerde tırnak yeme davranışı hariç, hiç bir davranışta süreklilik gözlenmemiştir.

Zaman yönetimi becerisi yüksek olan öğrencilerin, akademik başarıları da yüksektir. Zaman yönetiminin akademik başarı üstündeki önemi yadsınamaz. Öğrencilerin zamanı yönetmek konusundaki farkındalıklarının arttırılması akademik başarıların da mutlak suretle artıracaktır. Zaman yönetimi becerisi, aynı zamanda pozitif yönde birer alışkanlık olduğundan, küçük yaşlardan itibaren bu becerinin kazandırılması önemlidir. Bu becerinin henüz ilkokul yılarında öğrenilmesi oldukça önemlidir (Kibar, Fidan ve Yıldıran, 2014).

Araştırma sonucunda, yaşanılan bu problemler karşısında, ailelerin; çocuklarıyla, öğretmenleriyle konuşmayı tercih ettiklerini, uzmana göndermeyi ya da çocuğu sevdiği bir şeyden mahrum bırakarak sorunu çözme noktasında adımlar atabileceklerini belirtmişlerdir.

İlköğretim birinci kademesine denk gelen 7-11 yaş grubu, anne-baba ve öğretmenlerine, diğer kademelerdeki öğrencilere kıyasla daha büyük oranda bağımlıdırlar. Bu açıdan ilköğretim birinci kademesinde, öğretmen ya da velilerle işbirliği yapılmadan yürütülen rehberlik çalışmalarının başarı oranı oldukça azdır. (Akman, 2002). Kişilik gelişiminin büyük oranda tamamlandığı erken çocukluk döneminde, çeşitli sebeplerden dolayı meydana gelen davranış problemleri, çocuğun ileriki yaşamında arkadaşlarıyla ve sosyal çevresiyle olan ilişkilerini de olumsuz yönde etkileyecektir. Bu nedenle davranış problemlerinin erken dönemde belirlenerek nedenlerinin öğrenilmesi, davranışın kalıcı olmaması açısından son derece önemlidir. Bunun için de öğretmenlerle ve aileler işbirliği yapmalı, çocuklar gözlenerek bu davranışların ne zamanlarda ve ne sıklıkla ortaya çıtığı belirlenmelidir. (Taner Derman ve 
Başal, 2013) Çocuklarda görülebilecek davranış problemlerinin çözümü noktasında çocuk gelişim uzmanı, çocuk psikologlarının ya da rehber öğretmenlerden yardım istemek doğru olacaktır.

Duygusal ve davranışsal problemler yaşayan çocukların erken belirlenmesi ve onlara ihtiyaç duydukları hizmetlerin sunulması oldukça elzemdir. Okullarda rehber öğretmenler, okullarda ruh sağllğı hizmetleri olarak ifade edilen hizmetlerin sunulmasında ciddi bir role sahiptir (Çokamay, Kapçı ve Sever, 2017). Ancak mevcut hizmetlerden çoğu çocuk yararlanamamaktadır (Uğur Baysal ve diğg. ,2004). Çelenk (2003) çalışmasında, eğitimine destek veren ve okulla ortak bir tavır ortaya koyan ailelerin çocuklarının, diğer çocuklara nazaran daha başarılı oldukları sonucuna ulaşmıştır. Çiftçi ve Nedim Bal (2015) çalışmalarında buna benzer bir sonuç bulmuşlardır. Ancak rehber öğretmenler bu çalışmada, okula ve okul ruh sağlığı hizmetlerine ailelerin katılımları hususunda isteksiz olduklarını ifade etmişlerdir. Erdoğan ve Demirkasımoğlu (2010) çalışmalarında da, öğretmenler ve yöneticilerce, ailelerin okula katılımları pasif ve isteksiz bulunmuştur. Bu bulgular da Nedim Bal (2015) çalışmasında rehber öğretmenlerin görüşleriyle örtüşmekte ve çalışma bulgularımızı destekler niteliktedir. Çünkü görüşülen 11 aile ferdinden yalnızca 5'i bir uzmana (Psk danışman, psikolog, çocuk gelişim uzmanı vb.) giderim demiştir.

Çalışma bulguları 1şığında, yaşanan sorunlar üzerine bir uzmana göndermek bir yöntem olsa da alan yazında yapılmış çalışmalarda ailelerin okul ruh sağlığı hizmetlerine katılımlarının isteksizliği de vurgulanmıştır. Bu çalışmaya benzer bir sonuçta Erdoğan ve Demirkasımoğlu (2010) çalışmalarında ulaşmıştır. Çalışmalarında öğretmenlerin ve idarecilerin, ailelerin eğitim sürecine katılmaları gerektiği hususunda hemfikir oldukları; ancak pek çok velinin uygulama noktasında aynı hassasiyeti göstermediği sonucuna ulaşılmışlardır. Yine ailelerin büyük kısmının eğitim sürecine katılım noktasında istekli olmadığı görülmüştür. Katılım daha çok ailelerin okula gelip bilgi alması ya da toplantılara katılmalarıyla sinırlıdır.

\section{Sonuç}

Sonuçları incelediğimiz zaman; çalışmaya 11 aile üyesi katılmıştır. Bu aile üyelerinin 6 tanesi anne 5 tanesi babadan oluşmaktadır. Tüm katılımcıların 
yaş ortalamasına baktığımız zaman 35 ile 44 yaş arasındadır. 8 kişi lisans eğitimini, 2 kişi lise eğitimini ve 1 kişi de yüksek lisans eğitimini tamamlamıştır. Ayrıca; 2 kişinin öğretmen, 2 kişinin ev hanımı, 4 kişinin memur, 1 kişinin banka memuru, 1 kişinin polis ve 1 kişinin de avukat olduğu görülmektedir.

Bu demografik özellikler ışığında aile üyeleri sık sık çocukları ile problem yaşadıklarını ifade etmişlerdir. Özellikle sınav kaygısı, arkadaş ilişkilerinde yaşanan problemler, anne baba çocuk ilişkisinde yaşanan problemlerin yoğunluğu, çocukların şiddet içerikli davranışlarının olması, ders ve sınav esnasında zamanı kontrol edememe bu yüzden de kaygı yaşama ve akademik başarılarının düşük olması, çocukların çalışma isteksizliği, tırnak yeme gelecek hedeflerinin olmaması ve sınıf okul kurallarına uymamaları aileler için çocuklarında yaşadıkları psikolojik problemler olarak ifade edilmektedir. Problemlere bağlı olarak ailelerin bu problemler karşısında nasıl çözüm yollarına başvurduklarına baktığımız zaman ise; çocukları ile konuştuklarını, öğretmenleri ile görüştüklerini, sevdiği şeylerden mahrum bırakarak uzmandan görüş aldıklarını, bazen de diğer öğretmenlerden ve diğer ailelerden fikir aldıklarını ifade etmişlerdir. Ancak bu çözüm yollarının genellikle yeterli olmadığını düşünmektedirler. Yardım alınması gereken kişilerin psikolojik danışmanlar, psikologlar ve psikiyatriler olduğunu ifade etmektedirler.

$\mathrm{Bu}$ çalışma odak grup görüşmesine bağlı olarak hazırlanmış ve sadece 11 aile üyesini kapsayan bir çalışma olması açısından sınırlılık göstermektedir. Bu çalışmanın kapsamı daha geniş kitlelere ulaşılarak, daha fazla gereksinimler görülmeye çalışılabilir. Araştırmacılar daha sonraki çalışmalarda daha geniş aile üye kitlesine ulaşabilir, çocukların gereksinimleri ve ailelerin gereksinimleri incelenebilir ve uygulamacılar bu gereksinimlere bağlı olarak ailelere yönelik aile eğitim ve aile danışmanlık programları hazırlayabilir. Okuldaki rehberlik hizmetlerinin, gereksinimlere bağlı olarak etkinlikler düzenlemesi konusunda da yıllık çalışma planlarında yer verilebilir. 


\title{
EXTENDED ABSTRACT
}

\section{Investigation of Psychological Counseling Needs of Families of Children in Primary School}

\author{
Ayşe Bengisoy - Melih Burak Özdemir \\ Lefke Europe University
}

The family system is a system that meets the love and the needs of a child. This system is one of the most basic psychological requirements. While the family meets these needs, it also meets the social needs of a child, such as, belonging to a group, being in a trustworthy place, providing respect and knowing self-worth that is considered important. In this sense, it creates a healthy atmosphere that enables to function in a way that protects and educates a child. In this structure, the family members will gain the opportunity to become independent and dependent in the sense of expressing and recognizing themselves as a family member (Özkan \& Kılıç, 2013). It is without doubt that parents are educators of their own children and this role cannot be taken from them. The structure of what is called the school system, offers opportunities that parents cannot provide to their children as it fulfils the child's new needs.

At this point, the school-family cooperation is essential for completing the educational activities required, as it helps develop a positive relationship between members of staff at the school and the families in order for both parties to be satisfied. A research was conducted in the 2018-2019 academic year. The study was a qualitative study in which focused on two methods to analyse the obtained data in the qualitative study. One of these methods was a descriptive analysis method and the other was content analysis. The descriptive analysis method was used as the superficial of the collected data. In the descriptive analysis method, the data were summarized and interpreted according to a set of pre-categorized thoughts.

The data was collected through interviews. Data collection tools: prior the study, a literature review was conducted on developmental characteristics of primary school learners and the possible problems that their families could face. In the light of this information, some questions were sent to 5 academic 
staff and a related advisor in order to be examined and evaluated. Accordingly, 5 semi-structure open-ended questions were created. Pilot interviews were conducted with two family members of the learners who are still in their primary education process. In consequence of having consistent flow of questions and not having any negative feedback, the questions were not changed. The participants were informed about the reasons why they were asked to participants in the research, and they were explained where the interview data would be used. In addition to this, the participants were requested for their permissions to record their voices however, 6 of them did not accept to be recorded, whereas 5 of the participants permitted to record their interviews. The interviews of the six participants who did not accept to record their interviews, were reported in written form. In addition, all the interviews were conducted face to face and lasted approximately 20 to 25 minutes. Data analysis; the data which was gathered through face to face interactions was turned into written documents and analysed with descriptive analysis technique. According to the findings of the research, it was found that 6 of 11 family members are mothers, 5 of them are fathers and their average age is between 35 to 44 .

Family members who took part in the study stated that they often encountered problems, especially exam anxiety, not being able to manage the time, problems with parents and friends, non-compliance with school and class rules, nail biting as well as physical violence. It was also expressed by these family members that they need a psychological counselor, psychologist or psychiatrist as the solutions they found were inadequate. In the present study, students' problems with their friends and learning disabilities were explained by parents. The findings in the literature support the findings of the current study. In their study, Nalbant and Bababoğlu (2016) concluded that students had problems with friends, teachers and administrators at school. Uğur Baysal, Özmen, Parman, Sahip, Bulut and Gökçay (2004) concluded that learning disabilities and behavioral problems are highly encountered. Similar results were also obtained from studies in other countries. It can be said that the results of these studies are compatible with the current research findings. As part of this research, it can be suggested that; the scope of the study can be expanded by reaching the wider masses to see more necessities. In later studies, researchers can reach extended family members, the needs of children and the needs of families can be examined, and based on 
these needs, family education and family counseling programs for families can be prepared by practitioners.

\section{Kaynakça / References}

ASAGM (Aile ve Sosyal Araştırmalar Genel Müdürlüğü) (2008). 5. Aile Şurası 'Aile Destek Hizmetleri Bildirileri', Ankara.

Akman, Y. (2002). Okullardaki Konsültasyon Çalışmaları ve Ruh Sağlığı Konsültasyon Modeli. Türk Psikolojik Danışma ve Rehberlik Dergisi, 2(18),

Aydın, İ. (2005). Okul çevre ilişkileri. Y. Özden (Ed.), Eğitim ve Okul Yöneticiliği El Kitabı (s.161-185). Ankara: Pegem A Yayıncilık.

Cömert, D. ve Güleç, H. (2004). Okulöncesi Eğitim Kurumlarında Aile Katılımının Önemi: Öğretmen- Aile - Çocuk ve Kurum. Afyon Kocatepe Üniversitesi Sosyal Bilimler Dergisi, 6(1).

Çelenk, S. (2003). Okul Başarısının Ön Koşulu: Okul Aile Dayanışması. İlköğretimOnline 2(2), 28-34.

Çokamay, G., Kapçı, E.G. ve Sever, M. (2017). Okul Ruh Sağlığı Hizmetlerinde Yaşanan Sorunlar: Psikolojik Danışmanların Görüşleri. İlköğretim Online, 16(4), 1395-1406,. doi: 10.17051/ilkonline.2017.342962

Çiftçi, M. ve Nedim-Bal, P. (2015). Ortaokul öğrencilerinin anne-baba katılım düzeyi ile akademik başarıları arasındaki ilişkinin incelenmesi. Journal of Human Sciences, 12(1), 363-384.

Demirci, İ. ve Erden, S. (2016). Bilişsel davranışçı yaklaşıma dayalı grupla psikolojik danışma uygulamasının 8. sınıf öğrencilerinin sınav kaygısına etkisi. Marmara Üniversitesi Atatürk Eğitim Fakültesi Eğitim Bilimleri Dergisi, 43, 67-83. doi: 10.15285/ebd.51646

Ekiz, D. ve Koçyiğit, Z. (2013). Sınıf öğretmenlerinin 'öğretmen' kavramına ilişkin metaforlarının tespit edilmesi. Kastamonu Ĕ̆itim Dergisi, 21(2), 439-458.

Erbaş, D. (2002). Problem Davranışların azaltılmasında olumlu davranışsal destek planı hazırlama". A.Ü. Eğitim Bilimleri Fakültesi Özel Eğitim Dergisi, 3(2),41-50.

Erdoğan, Ç. ve Demirkasımoğlu, N. (2010). Ailelerin eğitim sürecine katılımına ilişkin öğretmen ve yönetici görüşleri. Kuram ve Uygulamada Eğitim Yönetimi Dergisi, 16(3), 399-431.

Eroğlu E. S. (2009). Saldırganlık davranışının boyutları ve ilişkili olduğu faktörler: Lise ve üniversite öğrencileri üzerine karşılaştırmalı bir çalışma. Selçuk Üniversitesi Sosyal Bilimler Enstitüsü Dergisi, 21, 205-221. 
Gentile, A. D., Lynch, J. P., Linder, R. J. ve Walsh, A. D. (2004). The effects of violent video game habits on adolescent hostility, aggressive behaviors and school performance. Journal of Adolescence, 27, 5-22.

Gudlaugsdottir, R. G., Vilhjalmsson, R., Kristjansdottir, G., Jacobsen, R. ve Meyrowisch, D. (2004). Violent Behaviour Among Adolescent in Iceland: A National Survey. International Journal of Epidemiology, 33.

Gürsu, O. (2015). Değişen dünyada aile ve psikolojik problemler. Dicle Üniversitesi İlahiyat Fakültesi Dergisi,17(1).

Kavakçı, Ö., Güler, A. S. ve Çetinkaya, S. (2011). Sınav kaygısı ve ilişkili psikiyatrik belirtiler. Klinik Psikiyatri, 14, 7-16.

Hamamcı, Z. ve Sevim, S. A. (2004).Türkiye'de Aile Rehberliği Çalışmaları. Türk Psikolojik Danışma ve Rehberlik Dergisi, 3(22).

Hatunoğlu, A. ve Hatunoğlu, Y. (2006). Okullarda Verilen Rehberlik Hizmetlerinin Problem Alanları. Kastamonu Ĕ̆itim Dergisi, 14(1), 333-338.

Herdem, F.S ve Bozgeyikli, H. (2013). İköğretime devam eden parçalanmış ve tam aile çocuklarının rehberlik ihtiyaçlarının karşılaştırılmalı olarak incelenmesi. OPUS-Türkiye Sosyal Politika ve Çalışma Hayatı Araştırmalan Dergisi, 3(4).

Işık, T. Y. (2011). Ah bir büyüse: Çocuk ve ergen psikolojisi. (1.Bsk), İstanbul: Doğan Yayıncllı; 83-90.

Kibar, B., Fidan, Y. ve Yıldıran, C. (2014). Öğrencilerin zaman yönetimi becerileri ile akademik başarıları arasındaki ilişki. Business \& Management Studies: An International Journal, 2(2), 136-153

Karasar, N. (2005). Bilimsel arastirma yontemi. Ankara: Nobel Yayin Dagitim,151-152.

Kuş, E. (2003). Nicel-nitel araştırma teknikleri.Ankara: Anı yayınclık.

Minibaş, J. (1988). Tırnak yeme. Yaşadıkça Eğitim, 4, 17-18.

Nalbant, A. ve Babaoğlu, E. (2016). Risk altındaki öğrenciler: Yozgat. E-Uluslararası Ĕ̆itim Araştırmaları Dergisi, 7(3), 11-30. doi:10.19160/e-ijer.35964

Özeke Kocabaş, E. (2006). Eğitim sürecinde aile katılımı: Dünyada ve Türkiye'deki çalışmalar. Türk Psikolojik Danışma ve Rehberlik Dergisi, 3(26).

Özgüven, E. (2001). Ailede iletişim ve yaşam. Ankara: PDREM yayınları.

Özkan, Y. ve Kılıç, E (2013). Ailenin psiko-sosyal destek ihtiyacını karşılamada yeni bir model önerisi: Aile sağlığı merkezlerinde aile psiko-sosyal destek birimi. Sosyal Politika Çalışmaları, 13(7).

Panayiotis, S., Anna, P., Charalambos, T. ve Chrysostomos, L. (2010). Prevalence of bullying among Cyprus elementary and high school students. International Journal of Violence and School, 11, 114-128. 
Patton, M. Q. (1990). Qualitative evaluation and research methods. SAGE Publications, Inc.

Salı, G. (2014). Okulöncesi dönem çocuklarında akran ilişkilerinin ve akran şiddetine maruz kalmanın çeşitli değişkenler açısından incelenmesi. Çukurova Üniversitesi Ĕ̆itim Fakültesi Dergisi, 43(2), 195-216.

Sezer, A., Kolaç, N. ve Erol, S. (2013). Bir İlköğretim okulu 4, 5, ve 6. sınıf öğrencilerinin saldırganlık düzeylerinin anne baba tutumları ve bazı değişkenler ile ilişkisi. MÜSBED, 3(4), 184-190. 10.5455/musbed.20131204095705

Şahin, H., Günay T. ve Batı, H. (2006).İzmir İli Bornova ilçesi lise son sınıf öğrencilerinde üniversiteye giriş sınavı kaygısı.Sürekli Tıp Eğitimi Dergisi, 15(6), 107113.

Şimşek, H. ve Yıldırım, A. (2011). Sosyal bilimlerde nitel araştırma yöntemleri. Ankara: Seçkin Yayıncılık.

Taner, I. (2011). Ah bir büyüse. Çocuk ve Ergen Psikolojisi. Birinci Baskı, İstanbul: Doğan Yayıncılık, 83-90.

Taner, Derman, M. ve Başal, H. A. (2013). Okulöncesi çocuklarında gözlenen davranış problemleri ile ailelerinin anne-baba tutumları arasındaki ilişki. Amasya Üniversitesi Eğitim Fakültesi Dergisi 2(1), 115-144.

Uğur-Baysal, S., Özmen, B., Parman, T., Sahip, Y., Bulut, A. ve Gökçay, G. (2004). Mental health screening project in Istanbul Turkey. Health service applications. Journal of School Health, 74, 341-343.

Yavuzer, H. (2003). Ana-Baba ve Çocuk. (16. Basım). İstanbul: Remzi Kitabevi.

Yıldırım, İ. (2007). Üniversite seçme sınavına hazırlanan Türk öğrencilerde depresyon, sınav kaygısı ve sosyal destek. Eğitim Araştırmaları, 29, 171-184.

Yıldırım, M.C. ve Dönmez, B. (2008). Okul-aile işbirliğine ilişkin bir araştırma. Elektronik Sosyal Bilimler Dergisi, 7(23), 98-115.

Yörükoğlu, A. (1982). Çocuk ruh sağhı̆̆ı. Ankara, Türk Tarih Kurumu Basımevi.

Yıldırım, A. ve Şimşek, H. (2005). Sosyal bilimlerde nitel araştırma yöntemleri. Ankara: Seçkin Yayıncılık.

Yıldırım, A. ve Şimşek, H. (2006). Sosyal bilimlerde nitel araştırma yöntemleri. Ankara: Seçkin Yayıncılık.

Yurdagül, H. (2005). Faktör analizinde KMO ve bartlett testleri neyi ölçer?.Ankara: Hacettepe Üniversitesi Yayınları. 


\section{Kaynakça Bilgisi / Citation Information}

Bengisoy, A. ve Özdemir, M. B. (2020). İlköğretime devam eden çocukların ailelerinin psikolojik danışma gereksinimlerinin incelenmesi. OPUS-Uluslararası Toplum Araştırmaları Dergisi, 15(25), 3528-3550. DOI: 10.26466/opus. 634810 